\title{
Doi 10.5943/ppq/6/2/6
}

\section{First report of Phomopsis sp. on Aloe vera in India}

\author{
Avasthi $\mathbf{S}^{1}$, Gautam $\mathrm{AK}^{2}$ and Bhadauria $\mathrm{R}^{3^{*}}$ \\ ${ }^{1}$ School of Studies in Botany, Jiwaji University, Gwalior- 474012 (M.P.) India. \\ ${ }^{2}$ Faculty of Agriculture, Abhilashi University, Mandi 175045, Himachal Pradesh, India
}

Avasthi S, Gautam AK, Bhadauria R 2016 - First report of Phomopsis sp. on Aloe vera in India. Plant Pathology \& Quarantine 6(2), 176-179, Doi 10.5943/ppq/6/2/6

\begin{abstract}
In rainy season of 2010 and 2011, leaves of Aloe vera were found infected with leaf spot disease. The leaves with typical symptoms of disease were collected from different nurseries and botanical gardens of Gwalior, Madhya Pradesh, India. Disease spots were observed on the adaxial surface and tip of leaves. Based on its morphological and cultural characteristics, the pathogen was identified as Phomopsis sp. This is the first report of leaf spot caused by Phomopsis sp. on A. vera in India.
\end{abstract}

Key words - Aloe vera - India - leaf spot - Phomopsis sp.

\section{Introduction}

Aloe vera is a green cactus-looking plant with beautiful rosette pattern of leaves. The average height of plant is about $80-100 \mathrm{~cm}$ with prickly leaves that hold translucent gel. The raw pulp contains about $98.5 \%$ water, whereas inner fillet gel has approximately $99.5 \%$ water (Eshun \& $\mathrm{He}$ 2004). The remaining $0.5-1 \%$ solid material contains more than 200 bioactive chemical compound like vitamins, minerals, enzymes, mono and polysaccharides, sugar, lignin, phenolic compounds and organic acids (Boudreau \& Beland 2006, Lanjhiyana et al. 2011). Aloe gel is widely used in beauty products, diet supplements, health juices and pharmaceutical purposes.

A survey of various nurseries and botanical gardens of Gwalior, Madhya Pradesh, India was carried out in 2010-11 to study the diversity of diseases associated with A. vera. During the survey a leaf spot disease was observed from various surveyed localities. The occurrence of leaf spot infection on A. vera poses a concern not only over the morphology of the plant but also on quality and quantity of the mucilaginous gel, which is used in herbal and cosmetic industries. The main objective of the present study was to isolate and identify fungal pathogen associated with leaf spot disease.

\section{Materials \& Methods}

\section{Collection of disease samples and isolation of pathogen}

Diseased samples were collected from various $A$. vera growing nurseries and botanical gardens of Gwalior, Madhya Pradesh and brought into the laboratory for further isolation studies. Infection on living leaves was photographed with a digital camera (Sony DSC-X80) and then 
subjected to mycological and plant pathological analysis. Collected diseased samples were washed thoroughly with running tap water to remove the surface contaminants. These were then cut into small pieces with a sterilized scalpel and surface sterilized with $2 \%$ sodium hypochlorite solution for 90 seconds. These tissues were washed 3-4 times with sterilized distilled water and aseptically transferred onto autoclaved potato dextrose agar (PDA, containing $1.0 \mathrm{mg} / \mathrm{ml}$ chloramphenicol) medium in petri plates. Inoculated petri plates were incubated at $25 \pm 2{ }^{\circ} \mathrm{C}$ for 5 to 6 days and the growth of fungal colonies were recorded every day. The cultural and morphological characteristics of the isolates were studied to identify the fungus associated with the disease. For microscopic observations, fungal tissues were mounted in lactophenol cotton-blue mixture and observed using a routine compound microscope.

Isolated fungi were identified on the basis of their morphological/cultural characteristics (shape, size and colour of colony) and microscopic features (characteristics of mycelium, shape, size of conidia). Micrometry was also performed to identify the isolated fungus in terms of length, breadth and diameter of conidia. The identification of the pathogen was also confirmed at Indian Type Culture Collection (ITCC), IARI, New Delhi, India, where the cultures were deposited. Pathogenecity test was done to complete Koch's postulates.

\section{Results}

After the survey of two consecutive years it was noted that, leaf spot disease on A. vera was observed only in rainy season (July-August). The percentage frequency of isolated fungus was ranged between $5-10.5 \%$.

Spots were observed on the adaxial surface and tip of leaves during the rainy season. Initially spots were small and maroon-brown in colour. Gradually spots became enlarged, sunken, dark brown in colour with a maroon margin. Later, these spots turned black, many small black spots were speckled on the centre of the spots, and extended up to $0.4-0.9 \times 0.4-0.6 \mathrm{~cm}$. Disease was found only in survey period from July to August (Fig. 1).

Developing colonies on PDA were extremely variable, woolly to cottony, white or whitish, pale to light brown. Two types of conidia were observed upon microscopic examinations. The alpha $(\alpha)$ conidia were hyaline, fusiform to ovate, straight, aseptate and frequently biguttulate, measuring 2.5-3.7 $\times 2-2.5 \mu \mathrm{m}$. The beta $(\beta)$ conidia were filiform, sigmoidal, and hyaline, measuring 3.7-4 × 2.3-3 $\mu \mathrm{m}$ (Fig. 2A, B).

Based on its morphological and cultural characteristics, the pathogen was identified as Phomopsis sp. The Indian Type Culture Collection (ITCC), IARI, New Delhi India (\# ITCC7802.10) confirmed the identity. Artificially inoculated leaves showed symptoms similar to natural diseased leaves, and the fungus was re-isolated from the leaves, thus confirming pathogenicity of Phomopsis sp. No symptoms appeared on control leaves sprayed with sterile distilled water.

\section{Discussion}

Taxonomically the genus Phomopsis is placed under class Sordariomycetes, order Diaporthales, family Diaporthaceae. To date, almost 1000 Phomopsis epithets have been recorded (www.indexfungorum.org) on a wide variety of plant hosts like cane and grape in Ohia (Nita et al. 2008), leaf spots on strawberry (Eshenaur \& Milholland 1989), Colorado blue spruce in Michigan (Igoe et al. 1995), Phomopsis blight of brinjal (Thippeswamy et al. 2006), cucurbits (Shishido et al 2006) and many more. Various leaf spots of $A$. vera have been reported to be caused by Fusarium phyllophilum (Kishi et al. 1999), Alternaria alternata (Manjul et al. 2008, Bajwa et al. 2010, Abkhoo 2014), A. tenuissima (Vakalounakis et al. 2015), Colletotrichum gloeosporioides (Avasthi et al. 2011), Curvularia lunata and C. ovoidea (Avasthi et al. 2015a), Fusarium oxysporum (Kawuri et al. 2012), Nigrospora oryzae (Zhai et al. 2013), Phoma betae (Avasthi et al. 2013), and Sphaeropsis sapinea (Kamil et al. 2014) from various parts of the world including India. A collar and root rot disease caused by Penicillium purpurogenum was also found associated with this plant (Avasthi et al. 2015b). No record of Phomopsis sp. is so far available on A. vera. Therefore, this is the first report of leaf spot disease on A. vera caused by Phomopsis sp. in India. Since A. vera is 
known as the source of several important products of nutritional and therapeutic value, the leaf spot disease caused by Phomopsis sp. deserves special attention.

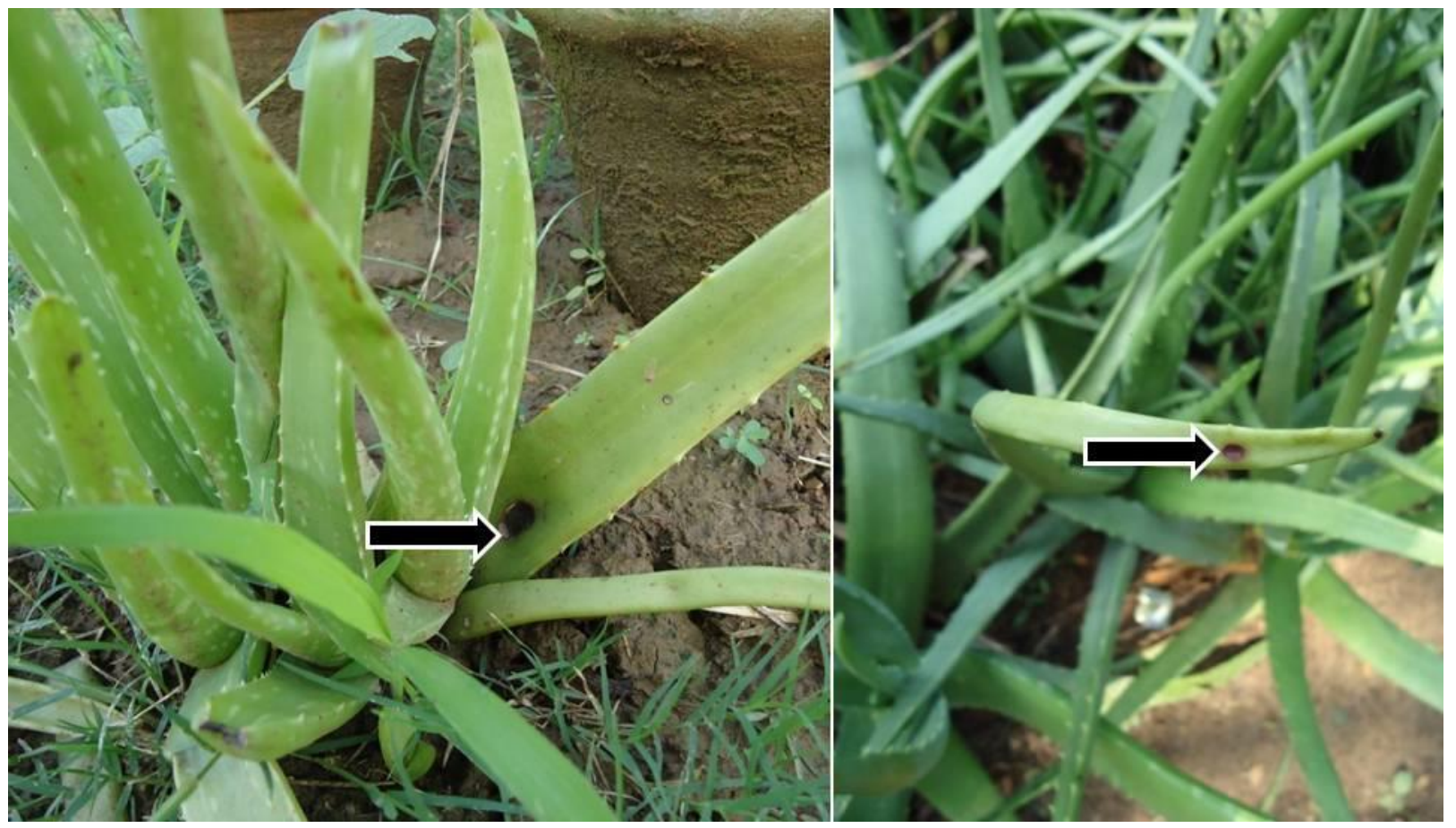

Fig 1 - Symptoms of Phomopsis leaf spot disease on Aloe vera.

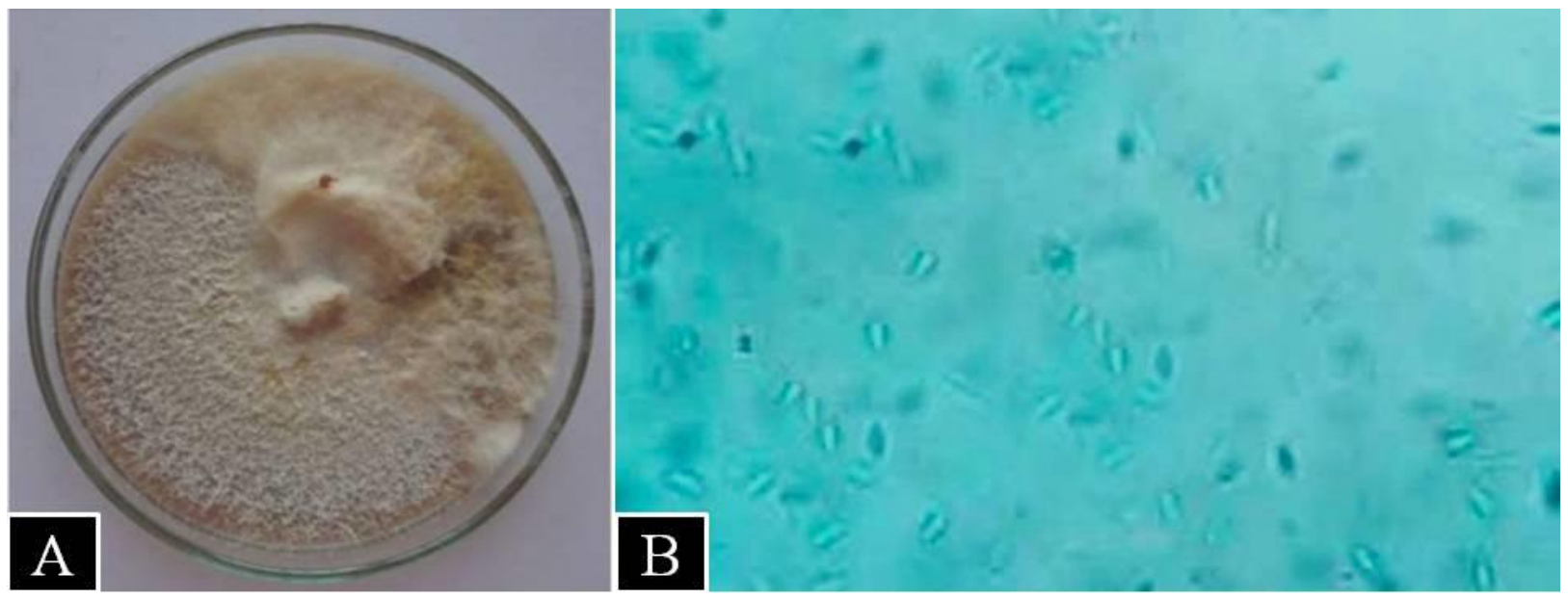

Fig 2 - Phomopsis sp. A: Mature colony on PDA. B: Microscopic view of conidia.

\section{Acknowledgements}

The authors thank Head, School of Studies in Botany, Jiwaji University Gwalior, Madhya Pradesh, India for providing essential laboratory facilities and support to conduct this research work successfully.

\section{References}

Abkhoo J. 2014 - Evidence of Alternaria alternate causing leaf spot of Aloe vera in Iran. Journal of Phytopathology 162, 516-518.

Avasthi S, Gautam AK, Bhadauria R. 2011 - First report of anthracnose disease of Aloe vera caused by Colletotrichum gloeosporioides. Journal of Research in Biology 5, 408-410. 
Avasthi S, Gautam AK, Bhadauria R. 2013 - First report of Phoma betae on Aloe vera in India. Archives of Phytopathology and Plant Protection 46, 1508-1511.

Avasthi S, Gautam AK, Bhadauria R. 2015a - Occurrence of leaf spot diseases on Aloe vera (L.) Burm.f. caused by Curvularia species from Madhya Pradesh, India. Biodiversitas 16, 79-83.

Avasthi S, Gautam AK, Bhadauria R. 2015b - First report of Penicillium purpurogenum causing collar and root rot infection in Aloe vera. Plant Pathology \& Quarantine 5, 20-24.

Bajwa R, Mukhtar I, Mushtaq S. 2010 - New report of Alternaria alternata causing leaf spot of Aloe vera in Pakistan. Canadian Journal of Plant Pathology 32, 490-492.

Boudreau MD, Beland FA. 2006 - An evaluation of the biological and toxicological properties of Aloe barbadensis (Miller). Journal of Environmental Science and Health, Part C Environmental Carcinogenesis and Ecotoxicology Reviews 24, 103-154.

Eshenaur BC, Milholland RD. 1989 - Factors influencing the growth of Phomopsis obscurans and disease development on strawberry leaf and runner tissue. Plant Disease 73, 814-819.

Eshun, K, He Q. 2004 - Aloe vera: A valuable ingredient for the food, pharmaceutical and cosmetic industries, A review. Critical Reviews in Food Science and Nutrition 44, 91-96.

Igoe MI, Peterson NC, Roberts DL. 1995 - A Phomopsis canker associated with branch die-back of Colorado blue spruce in Michigan. Plant Disease 79, 202-205.

Kamil D, Sharma DK, Devi TP, Singh M. 2014 - First report of leaf blight of Aloe vera caused by Sphaeropsis sapinea in India. Journal of Plant Pathology 96, 113.

Kawuri R, Suprapta DN, Nitta Y, Homma T. 2012 - Destructive leaf rot disease caused by Fusarium oxysporium on Aloe barbadensis Miller in Bali. Agricultural Science Research Journal 2, 295-301.

Kishi K, Furukawa T, Akot T. 1999 - Purple spot of aloe (Aloe arborescens Mill.) caused by Fusarium phyllophilum Nirenberg et O'Donnell (new disease). Annals of the Phytopathological Society of Japan 65, 576-587.

Lanjhiyana S, Garabadu D, Ahirwar D, Bigoniya P, Rana AC, Patra KC, Lanjhiyana SK. 2011Antihyperglycemic potential of Aloe vera gel in experimental animal model. Annals of Biological Research 2, 17-31.

Manjul P, Shubha T, Gurha SN, Tripathi VK. 2008 - Dry rot and leaf spot of Aloe barbadensis caused by Alternaria alternata. Annals of Plant Protection Sciences 16, 512-513.

Nita M, Ellis MA, Madden LV. 2008 - Variations in disease incidence of Phomopsis cane and leaf spot of grape in commercial vineyards in Ohio. Plant Disease 92, 1053-1062.

Shishido M, Yoshida N, Usami T, Shinozaki T, Kobayashi M, Takeuchi T. 2006 - Black root rot of cucurbits caused by Phomopsis sclerotioides in Japan and phylogenetic grouping of the pathogen. Journal of General Plant Pathology 72, 220-227.

Thippeswamy B, Krishnappa M, Chakravarthy CN, Sathisha AM, Jyothi SU, Kumar KV. 2006 Pathogenicity and management of phomopsis blight and leaf spot in brinjal caused by Phomopsis vexans and Alternaria solani. Indian Phytopathology 59, 475-481.

Vakalounakis DJ, Kavroulakis N, Lamprou KK. 2016 - Occurrence of leaf spot caused by Alternaria tenuissima on Aloe barbadensis in Greece. Plant Disease 100, 1015.

Zhai LF, Liu J, Zhang MX, Hong N, Wang GP, Wang LP. 2013 - The first report of leaf spots in Aloe vera caused by Nigrospora oryzae in China. Plant Disease 97, 1256. 